preparatory studies contended for by M. Pasteur as essential are only too likely to be underrated or overlooked.

The bearing of his views on the question of technical education, now so much spoken of in England, will be apparent to every reader of the following translation of a portion of the article referred to. Its introduction in this place would be incongruous were it not that the main object of the various essays published in this book was to ereate a public interest in science as a source of knowledge, and as a means of culture, without present regard to its material results. But the issues of studies animated by this spirit are incalculable; for, though undertaken with no practical intent, they are really the prime movers of all practice. If the purely scientific diseoverer die out, practical applications cannot long survive him.

The following three quotations are selected from Pasteur's article:

Few persons comprehend the real origin of the marvels of industry and the wealth of nations. I need no other proof of this than the employment more and more frequent in lectures and speeches, in official language, and in writings of all sorts, of the erroneous expression applied science. The abandonment of scientific careers by men capable of pursuing them with distinction was recently complained of in presence of a minister of the greatest talent. This statesman endeavored to show that we ought not to be surprised at this result, because in our day the reign of theoretic science yielded place to that of applied science. Notliing could be more erroneous than this opinion; nothing, I venture to say, more dangerous even to practical life, than the eonsequences which might flow from these words. They have rested in my memory as a proof of the imperious necessity of reform in our superior education. No, a thousand times no! There exists no eategory of sciences to which the name of applied science could be given. We have science and the applications of science, which are united to each other as the fruit and the tree on which it grew.

At one time the majority of the foremost disciples of the École Polytechnique followed the eareer of mathematical and physical sci- ence, and of the higher studies generally. In our day this fact is only a rare exception. It is not that the pupils of this great school are less numerous than formerly, or less capable than their predecessors, the Maluses, the Poissons, the Fresnels, to render their country illustrious by fruitful discoveries, but the course of events invites them to carry the fruit of their studies into the operations of industry, such as the working of mines, the construction of railways, ete.

The German nation has understood that there exists no applied science, but only the applications of science, and that these latter are only rendered valuable by the diseoveries which nourish them; while the constant preoceupation of our statesmen regarding public instruetion during fifty years has had prineipally for object primary and secondary education. They have forsaken the higher studies, particularly that of science, to the impulse they had received from the renovation of science in the eighteenth century.

Finally Tyndall says:

The opinions of so eminent a man regarding the relation of science to its applications, and to the general culture of the nation, merits our gravest attention.

Carlinvilite, Illinois

Charles Robertson

\section{CULTIVATION AND EVAPORATION}

To the Editor of Science: Dr. L. S. Frierson (in Sclence, March 24, 1922, p. 317) shows by his remarks the danger of confounding facts with their explanation. What "all practical farmers from the days of King Hamurabi to date" agree upon is the fact that cultivation helps plants in dry weather. But Dr. Frierson and I have differed as to the explanation of this fact-he believes that cultivation "stops evaporation, and thus conserves the store of soil water," whereas my view was that "a greater total surface is exposed to evaporation, and evaporation is therefore facilitated."

The remarks of Dr. H. A. Noyes (in ScIence, June 9, 1922, p. 610) throw further light on the subject. He believes that "cultivation lets air down in the soil, thereby increasing bac- 
terial activities which in turn cause the plants to get more food and grow larger on less moisture." In the Journal of Industrial and Engineering Chemistry for March, 1922, Dr. Noyes reported experiments where "fertilization has decreased the water requirements of plants over one half, when expressed as the amount of water necessary to produce one unit weight of plant." "It appears that if the soil solution is weak, the plant transpires more water in its attempt to make a normal growth."

The observations of Dr. Noyes seem to confirm my application of Bechhold's "capillary phenomenon" in agriculture (SCIENCE, July 22, 1921), because increased evaporation at the surface of the ground in the immediate neighborhood of the plant would mean a richer soil solution within reach of the plant roots; so that even if some water is lost, the plant can get its food requirements with less water. The uncultivated soil near the plant may even be robbed of its food and moisture by sidewise diffusion streams. As W. Kraus showed, the movement of salts in the Bechhold "phenomenon" is dependent upon evaporation at the exposed surfaces (Kolloid Zeitschrift, 28, 161, 1921.).

Another important factor is the rate at which the soil water reaches the plant roots. This must at least equal the speed at which moisture is evaporated by the leaf system, otherwise the wilting coefficient is reached and the plant droops. In this connection Sir E. J. Russell, director of the Rothamsted Experimental Station, pointed out that the availability of nutrients should properly be measured by the rate at which they reach the roots which absorb them. (J. Agri. Sci., 1, 327).

According to the Bechhold phenomenon, cultivation of the soil immediately above the roots (which is where cultivation takes place) increases evaporation there and the accelerated upward and sidewise diffusion streams carry the essential water and food with sufficient rapidity to favor plant growth. Russell says (Trans. Faraday Soc., February, 1922) that a crop of wheat weighing with its straw about four tons per acre, transpires during its lifetime about 1,000 tons of water per acre, the actual strength of the soil solu- tion varying from 0.0001 to 0.006 per cent. according to treatment.

Dry weather usually comes when the plant's leaves are well developed; and in any event it means a period of rapid evaporation from the leaves. Especially then has cultivation been found a life saver, and often an actual aid to growth.

The remarks of Dr. Cyril Hopkins (quoted by Dr. Frierson to support his view) that the soil is "stirred after each rain to prevent evaporation, and thus store up sufficient moisture in the soil to give the crop a good start," do not militate against my view; for Dr. Noyes' experiments show that cultivation, by allowing the plant to grow with less moisture early in the season, enables it to enter the drought period "with an accumulative reserve of soil moisture." This is a most important conclusion. It seems to me, however, that the Bechhold phenomenon of salt concentration or movement also explains why a plant may thrive on less water; for this lesser amount of water, enriched by diffusion, has the essential plant foods.

\section{RIDGEFIELD, CONN.}

Jerome Alexander

\section{REPOSITORIES FOR SCIENTIFIC PUBLICATIONS}

To the Edtor of ScIence: Recent discussion in SCIENCE as well as in other places is indicative of the increasing interest in efforts to extend limited funds so as to cover rapidly expanding scientific writings or to curtail such writings so as to bring them within the limits of the funds.

This interest is considerably augmented by the realization of workers in certain lines that there is also a problem of storage space for multitudinous papers and a kindred problem of finding time and energy for reading such as come to hand.

In the course of recent discussions with representatives of the University of California Press and the University of California committee on research $I$ have been impressed with the need for adoption of a general policy with regard to certain features (at least) of scientific publications.

It is my understanding that the University 